\title{
Effect of $3 \%$ topical trehalose on the rate of corneal re-epithelialization in patients undergoing photorefractive keratectomy
}

\section{Efecto de la trehalosa tópica al $3 \%$ en la velocidad de epitelización corneal en pacientes operados de queratectomía fotorrefractiva}

\author{
Alberto Haber ${ }^{1,2 *}$ and Eduardo J. Polania-Baron ${ }^{1}$ \\ ${ }^{1}$ Department of Cornea, External Diseases and Refractive Surgery, Instituto de Oftalmología Conde de Valenciana I.A.P.; ${ }^{2}$ Aris Vision Institute. Mexico \\ City, Mexico
}

\begin{abstract}
Purpose: To study the changes in corneal re-epithelialization rate in patients undergoing surface photorefractive keratectomy by using 3\% trehalose. Methods: This is a prospective, randomized, controlled clinical trial.The inclusion criteria were patients older than 18 years, with clinical and topographic criteria for refractive surgery, who agreed to participate in the protocol. Randomization was carried out to assign one eye of each patient to the control group with conventional treatment and the other eye to the experimental group with $3 \%$ trehalose plus conventional treatment. The free image processing software Image $J$ was used to quantify the area of de-epithelialization in square millimeters. Results: The average number of epithelialization days was of 2.984 days in the experimental group and of 2.954 days in the control group (not statistically significant; $p=0.1624063$ ). The area of de-epithelialization in the examination prior to reaching $100 \%$ epithelialization was of $4.255 \mathrm{~mm}^{2}$ in the experimental group and $3.1762 \mathrm{~mm}^{2}$ in the control group (not statistically significant; $\left.p=0.0899374\right)$. Conclusions: Topical instillation of $3 \%$ trehalose does not increase the rate of corneal re-epithelialization in patients undergoing photorefractive keratectomy.
\end{abstract}

Key words: Refractive surgical procedures. Photorefractive keratectomy. Re-epithelialization. Trehalose.

\section{Resumen}

Objetivo: Estudiar el cambio en la velocidad de epitelización corneal en pacientes sometidos a cirugía de queratectomía fotorrefractiva de superficie en los que se aplicó trehalosa al 3\%. Método: Se trata de un ensayo clínico prospectivo, aleatorizado y controlado. Los criterios de inclusión fueron ser mayor de 18 años, con criterios clínicos y topográficos para realizar cirugía refractiva, y aceptar participar en el protocolo. La asignación aleatoria se llevó a cabo para asignar a uno de los dos ojos de cada paciente para conformar el grupo control con el tratamiento convencional y el grupo de tratamiento con la instilación, además del tratamiento convencional, de trehalosa al 3\%. Para cuantificar el área de desepitelización en milímetros cuadrados se utilizó el software libre de procesamiento de imágenes Image J. Resultados: El promedio de días de epitelización en el grupo de casos fue de 2.984 días y en el grupo de control fue de 2.954 días (diferencia no estadísticamente significativa; $p=0.1624063$ ). El área de desepitelización en la revisión previa a alcanzar el 100\% de epi-

\section{Correspondence:}

*Alberto Haber

Vito Alessio Robles, 39

Col. Chimalistac, Del. Álvaro Obregón Date of reception: 17-02-2020

C.P. 01050, Mexico City, Mexico

E-mail: doctorhaber@gmail.com
Available online: 16-03-2021

Rev Mex Oftalmol (Eng). 2021;95(2):68-72

www.rmo.com.mx

2604-1731/@ 2020 Sociedad Mexicana de Oftalmología. Published by Permanyer. This is an open access article under the CC BY-NC-ND license (http://creativecommons.org/licenses/by-nc-nd/4.0/). 
telización en el grupo de casos fue de $4.255 \mathrm{~mm}^{2}$ y en el grupo de control fue de $3.1762 \mathrm{~mm}^{2}$ (diferencia no estadísticamente significativa; $p=0.0899374)$. Conclusiones: La trehalosa tópica al 3\% no aumenta la velocidad de epitelización corneal en pacientes sometidos a queratectomía fotorrefractiva.

Palabras clave: Procedimientos quirúrgicos refractivos. Queratectomía fotorrefractiva. Reepitelización. Trehalosa.

\section{Introduction}

Trehalose is a disaccharide, a key element for anhydrobiosis (the ability to survive almost complete dehydration) in many organisms ${ }^{1}$. The role of trehalose has expanded, and it has now been implicated in a variety of potential treatments in ophthalmology $\mathrm{y}^{2,3}$.

Trehalose is synthesized as a stress-sensitive factor when cells are exposed to environmental stresses, such as heat, cold, oxidation, desiccation, etc. When single-celled organisms are exposed to stress, they adapt by synthesizing large amounts of trehalose, which helps them retain cell integrity. This is believed to occur by preventing denaturation of proteins by trehalose, which would otherwise degrade under stress ${ }^{4}$.

Preclinical studies have shown that human primary fibroblasts transfected with genes of biosynthetic trehalose enzymes were able to survive desiccation up to 5 days ${ }^{5}$. Corneal epithelial cells incubated with trehalose were also able to survive desiccation ${ }^{6-8}$. Trehalose has been shown to protect corneal and conjunctival cells (including goblet cells) against apoptosis in a murine model of dry eye syndrome ${ }^{9,10}$, and against ultraviolet-induced oxidative damage in corneal cells ${ }^{11}$. In a murine model of dry eye syndrome, trehalose reduced the concentration of inflammatory cytokines in the conjunctiva ${ }^{9}$.

Clinical studies in which 3\% topical trehalose was instilled in patients with dry eye syndrome have shown a significant improvement in tear film stability and ocular staining ${ }^{12,13}$, as well as a faster regeneration after crosslinking, where some of its techniques include corneal de-epithelialization ${ }^{14}$.

Photorefractive keratectomy (PRK) is one of the most widely used refractive surgical options for patients who are not candidates for other subtractive refractive surgical techniques, such as LASIK (laser-assisted in situ keratomileusis). PRK includes corneal de-epithelialization before photoablation and corneal remodeling using excimer laser. The recovery process, as well as its main symptoms, are directly related to the epithelialization process, which takes place after 3-7 days on average; once the corneal epithelium has completely covered the surface of the cornea, symptoms and visual quality improve dramatically. Symptoms that occur in the corneal epithelialization phase after PRK include pain, foreign body sensation, photophobia, and blurred vision ${ }^{15-21}$.

The objective of this study is to evaluate the corneal re-epithelialization rate in patients undergoing PRK in whom $3 \%$ trehalose was applied.

\section{Methods}

This is a prospective, randomized, controlled clinical trial conducted at the Instituto Mexicano de Oftalmología in Mexico City. This study was conducted according to the ethical standards considered in the Helsinki declaration. Informed consent was written and distributed to the participants, which was read in its entirety in the presence of the principal investigator. Inclusion criteria were patients over 18 years of age, with clinical and topographic criteria to perform refractive surgery, who agreed to participate in the protocol. Exclusion criteria were patients under 18 years of age, with previous corneal surgery or pathology (severe dry eye syndrome, acute conjunctivitis, corneal scars, corneal ectasia, glaucoma, infectious keratitis), systemic pathology (including autoimmune diseases), using systemic (steroids, disease-modifying drugs, biologics [drugs used in severe cases of uncontrolled autoimmune disease]) or topical treatments (antibiotics, steroids, or lubricants in the last 6 weeks), or with a known allergy to any of the compounds to be used in both the control group and the treatment group.

Accepting a bilateral alpha error of $5 \%$ and a power of $80 \%$, the standardized difference (SD) was calculated, this being the quotient between the mean differences and the standard deviation $n=16 /(S D) 2$. In this study, the power increases when comparing both eyes.

Randomization was carried out generating random numbers with the help of a computer and the Labview program for the generation of a list, according to which each participant was assigned to conventional treatment or $3 \%$ trehalose, either for the right or left eye.

The treatment scheme in both eyes consisted of $0.15 \%$ hyaluronate (Hyabak ${ }^{\circledR}, 10 \mathrm{~mL}$ dropper bottle), one drop in each eye every 4 hours during waking hours for 10 days, $0.5 \%$ moxifloxacin (Vigamoxi ${ }^{\circledR}, 10 \mathrm{~mL}$ dropper bottle) one drop every 4 hours during waking 
hours for 10 days, and $0.1 \%$ fluorometholone acetate in suspension (Flumetol® $5 \mathrm{~mL}$ dropper bottle) one drop in each eye every 4 hours during waking hours for 5 days, followed by one drop in each eye every 8 hours during waking hours for 5 days and then discontinue. In the operated eye, $3 \%$ trehalose (Thealoz ${ }^{\circledR}, 10 \mathrm{~mL}$ dropper bottle) was indicated one drop every 6 hours for 10 days. The patients were provided with hyaluronate and trehalose, while they received a prescription for the antibiotic and the steroid.

During each visit, it was verified that the presentation and the commercial name coincided with what was prescribed. During the reviews they were explicitly asked about their adherence to treatment and instructed on how to set alarms on their mobile phones so as not to forget the instillation of the medications.

The surgery was performed by a single surgeon (AHO). During the intervention, an 8-mm circle was marked with a marker of the same diameter (MacRae Mini LASEK/PRK Well $8.0 \mathrm{~mm}$, Storz ${ }^{\circledR}$ ) for the area of de-epithelialization prior to laser ablation. De-epithelialization was carried out using the Mini-Blade instrument (Beaver ${ }^{\circledR}$ Visitec Int.). The NIDEK EC 5000 (NIDEK Inc) was used for excimer laser ablation. At the end of the procedure, a therapeutic contact lens (B\&L, polymacon, $14 \mathrm{~mm}$ diameter) was placed prior to the instillation of moxifloxacin in combination with dexamethasone as a prophylactic (Vigadexa ${ }^{\circledR} 0.5 \% / 0.1 \%$ ).

The first review was carried out 24 hours after the procedure, in which binocular visual acuity was recorded, the auto-kerato-refractometer measurement, and the presence of the contact lens, as well as corneal transparency, were examined through biomicroscopy.

At 72 hours, the second exam was performed, in which binocular visual acuity was recorded, autokeratorefractometry measurement, contact lenses were removed, and fluorescein staining and slit lamp evaluation with a cobalt blue filter was performed.

Digital photographs of the cornea were acquired (all were taken by the same person [not blinded] with the same camera [mechanical adapter to attach the Samsung $^{\circledR}$ Galaxy S 10 rear camera cell phone to the lens of the slit lamp]) as well as with fluorescein staining, to show the percentage of corneal epithelialization in both eyes (using a cobalt filter at medium intensity axial to the corneal plane).

Patients who did not reach $100 \%$ epithelialization at the time of the review had a new therapeutic contact lens placed after the exam and taking pictures.

The digital photographs were analyzed using the specialized software Image $\mathrm{J}$ (public domain digital image processing program; National Institutes of Health, $1.52 \mathrm{P}$ ). Using this specialized software, with artificial vision and RGB color threshold algorithms, the area in square millimeters of the fluorescein staining corresponding to the area without epithelium of the total corneal surface was determined.

Due to ethical and safety concerns, it was decided to perform the first fluorescein staining after 72 hours, and the photograph was taken only once a day. The corneal epithelialization rate was measured as the main variable. The review and the digital photographs happened every 24 hours after the second review until achieving $100 \%$ epithelialization in both eyes. The epithelialization of the right eye was compared with that of the left eye in each patient, with the control and treatment group defining randomization per participant.

In the statistical analysis, the deductive Student's t-test was used to evaluate the difference between the means of the two groups with the SPSS statistical package (IBM SPSS Statistics 26.0, 2019).

\section{Results}

Overall, 66 eyes of 33 patients were studied; $72.7 \%$ were women and the average age was $24.8 \pm 4.5$ years. Thirty-three eyes (16 right and 17 left) were randomized to the trehalose group and 33 eyes to the control group. The average days of epithelialization in the trehalose group was 2.984 days, and in the control group it was 2.954 days (difference not statistically significant; $p=0.1624063$ ).

The area of de-epithelialization before reaching 100\% epithelialization in the trehalose group was $4.255 \mathrm{~mm}^{2}$, and in the control group it was $3.1762 \mathrm{~mm}^{2}$ (difference not statistically significant; $p=0.0899374$ ) (Fig. 1).

No patient had any complications related to surgery (infections, haze or persistent epithelial defect).

\section{Discussion}

The application of trehalose restored the integrity of the ocular surface and suppressed the inflammatory and proteolytic MMP-9, as well as keratinization in preclinical studies in a dry eye animal model designed by $\mathrm{Li}$, et al. ${ }^{9}$.

In a randomized, double-masked, crossover, controlled clinical trial of 36 patients with moderate to severe dry eye syndrome, trehalose was the treatment that showed better results regarding ocular staining scores compared 


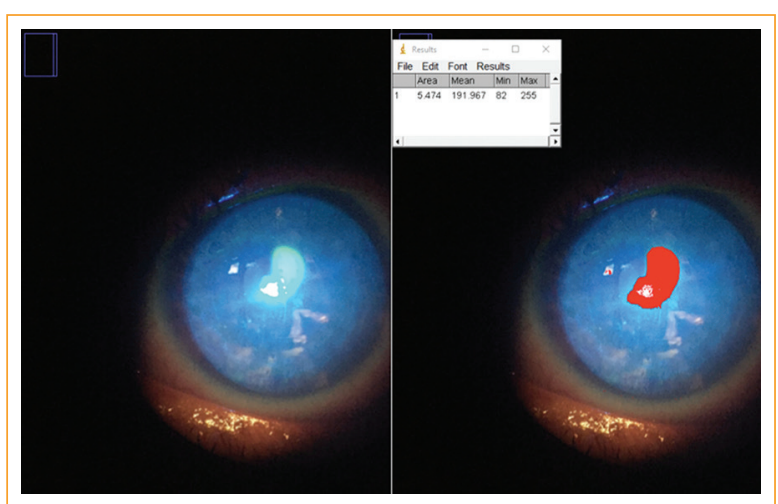

Figure 1. The fluorescein staining is shown in green and the delimitation of the epithelial defect is shown in red with the Image $\mathrm{J}$ program to calculate the deepithelialization area.

to two commercially available eye drops containing hyaluronate or hydroxypropylmethylcellulose ${ }^{6,12,13}$.

Another randomized, double-masked and controlled parallel-group study ${ }^{15}$ evaluating tear film thickness after treatment with artificial tears in patients with moderate dry eye disease, showed that a single instillation of trehalose $(30 \mathrm{mg} / \mathrm{mL})$ and sodium hyaluronate $(1.5 \mathrm{mg} / \mathrm{mL})$ increased the thickness of the tear film in patients with dry eye disease. The data also indicate a longer corneal retention of eye drops in the eyes that received trehalose.

We consider that these findings could be explained due to the greater efficacy of trehalose-based eye drops in the prevention of cell death due to desiccation, which is why it acts as a cytoprotective agent ${ }^{22}$, and as we mentioned earlier, its main activity is to help to treat dry eye in the clinical practice ${ }^{17}$ and to improve the objective and subjective parameters of tear quality in patients after refractive surgery ${ }^{23}$.

Therefore, this could mean that, if trehalose has a cytoprotective capacity, it could preserve normal cell morphology and cell membrane functions, as well as proliferative activity more effectively ${ }^{22}$, so it could be used in the ophthalmology practice as an agent to promote epithelialization during PRK or surface photoablation surgery.

Regarding the use of $3 \%$ trehalose in refractive surgery, there is only one clinical study in patients that underwent LASIK, in which qualitative and quantitative parameters of the tear film were evaluated before and after surgery in two groups of patients: one with $3 \%$ trehalose and another with standard treatment with artificial tears $^{23}$. This study did not evaluate the corneal re-epithelialization rate since there is no de-epithelialization during LASIK.

During surface photorefractive surgery or PRK, de-epithelialization and damage to corneal nerve plexuses $^{24}$ are induced, which are involved in postoperative pain. Corneal regeneration systems, such as fibronectin, integrins, collagenases, growth factors, and nerve factors, are sufficient to stimulate stromal and epithelial healing ${ }^{24-26}$. The corneal epithelialization rate is different when there are ocular or systemic diseases, so we consider that the subjects who participated in our study are an interesting study group to evaluate the usefulness of trehalose to improve the epithelialization rate in healthy subjects.

One of the limitations of our study is the number of exams to quantify the epithelialization area, because although it would have been more precise to instill fluorescein and carry out the photographic control every hour, this would not be an ethical practice.

\section{Conclusions}

Topical 3\% trehalose does not increase the rate of corneal epithelialization in patients undergoing PRK.

\section{Conflicts of interest}

The authors declare no conflicts of interest.

\section{Ethical disclosures}

Protection of human and animal subjects. The authors declare that the procedures followed were in accordance with the regulations of the relevant clinical research ethics committee and with those of the Code of Ethics of the World Medical Association (Declaration of Helsinki).

Confidentiality of data. The authors declare that they have followed the protocols of their work center on the publication of patient data.

Right to privacy and informed consent. The authors have obtained the written informed consent of the patients or subjects mentioned in the article. The corresponding author is in possession of this document.

\section{References}

1. Crowe JH, Hoekstra FA, Crowe LM. Anhydrobiosis. Annu Rev Physiol. 1992:54:579-99.

2. Cejka C, Kubinova S, Cejkova J. Trehalose in ophthalmology. Histol Histopathol. 2019;34:611-8.

3. Cejková J, Cejka C, Ardan T, Sirc J, Michálek J, Luyckx J. Reduced UVB induced corneal damage caused by reactive oxygen and nitrogen species and decreased changes in corneal optics after trehalose treatment. Histopathol. 2010;25:140316. 
4. Jain NK, Roy I. Effect of trehalose on protein structure. Protein Sci. 2009;18:24-36

5. Guo N, Puhlev I, Brown DR, Mansbridge J, Levine F. Trehalose expression confers desiccation tolerance on human cells. Nat Biotechnol. 2000;18:168.

6. Matsuo T. Trehalose protects corneal epithelial cells from death by $\mathrm{dr}$ ying. Br J Ophthalmol. 2001;85:610-2.

7. Hovakimyan M, Ramoth T, Löbler M, Schmitz K, Witt M, Guthoff R, et al Evaluation of protective effects of trehalose on desiccation of epithelia cells in three dimensional reconstructed human corneal epithelium. Curr Eye Res. 2012;37:982-9.

8. Aragona P Colosi P, Rania L, Colosi F, Pisani A, Puzzolo D, et al. Protective effects of trehalose on the corneal epithelial cells. ScientificWorldJournal. 2014;2014:717835.

9. Li J, Roubeix C, Wang Y, Shi S, Liu G, Baudouin C, et al. Therapeutic efficacy of trehalose eye drops for treatment of murine dry eye induced by an intelligently controlled environmental system. Mol Vis. 2012;18:317-29.

10. Chen W, Zhang X, Liu M, Zhang J, Ye Y, Lin Y, et al. Trehalose protects against ocular surface disorders in experimental murine dry eye through suppression of apoptosis. Exp Eye Res. 2009;89:311-8.

11. Cejková J, Cejka C, Luyckx J. Trehalose treatment accelerates the healing of UVB irradiated corneas. Comparative immunohistochemical studies on corneal cryostat sections and corneal impression cytology. Histo Histopathol. 2012;27:1029-40.

12. Matsuo T. Trehalose versus hyaluronan or cellulose in eyedrops for the treatment of dry eye. Jpn J Ophthalmol. 2004;48:321-7.

13. Matsuo T, Tsuchida $\mathrm{Y}$, Morimoto N. Trehalose eye drops in the treatment of dry eye syndrome. Ophthalmology. 2002;109:2024-9.

14. Ozek D, Kemer O. Effect of the bioprotectant agent trehalose on corneal epithelial healing after corneal cross-linking for keratoconus. Arq Bras Oftalmol. 2018;81:505-9.

15. Akcam HT, Unlu M, Karaca EE, Yazici H, Aydin B, Hondur AM. Autologous serum eye-drops and enhanced epithelial healing time after photorefractive keratectomy. Clin Exp Optom. 2018;101:34-7.
16. Marino GK, Santhiago MR, Santhanam A, Torricelli AAM, Wilson SE Regeneration of defective epithelial basement membrane and restoration of corneal transparency after photorefractive keratectomy. J Refract Surg. 2017:33:337-46.

17. Taneri S, Oehler S, MacRae S, Dick HB. Influence of a therapeutic soft contact lens on epithelial healing, visual recovery, haze, and pain after photorefractive keratectomy. Eye Contact Lens. 2018;44 (Suppl 1):S38-S43.

18. Ilhan A. Autologous serum eye drops accelerate epithelial healing after LASEK. Curr Eye Res. 2016;41:872.

19. Serrao S, Lombardo M. Corneal epithelial healing after photorefractive keratectomy: analytical study. J Cataract Refract Surg. 2005;31:930-7.

20. Verma S, Corbett MC, Marshall J. A prospective, randomized, double-masked trial to evaluate the role of topical anesthetics in controlling pain after photorefractive keratectomy. Ophthalmology. 1995;102:1918-24.

21. Zarei-Ghanavati S, Jafarpour S, Radyn-Majd A, Hosseinikhah-Manshadi H. Evaluation of early postoperative ocular pain after photorefractive keratectomy and corneal crosslinking. J Cataract Refract Surg. 2018;44: 566-70.

22. Hill-Bator A, Misiuk-Hojło M, Marycz K, Grzesiak J. Trehalose-based eye drops preserve viability and functionality of cultured human corneal epithelial cells during desiccation. Biomed Res Int. 2014;2014:292139.

23. Mateo Orobia AJ, Casas Pascual P, Cristóbal Bescós JA, Pérez García D, Peiro Embid C, Del Buey Sayas MA, et al. Effects of $3 \%$ trehalose as an adjuvant treatment after LASIK. Clin Ophthalmol. 2017;11:347-53.

24. Marshall J, Trokel SL, Rothery S, Krueger RR. Long-term healing of the central cornea after photorefractive keratectomy using an excimer laser. Ophthalmology. 1988;95:1411-21.

25. Kinoshita $\mathrm{JH}$. Physiological chemistry of the eye. Arch Ophthalmol. 1962;68:554-70.

26. Gandhi S, Jain S. The anatomy and physiology of cornea. Keratoprostheses Artif Corneas Fundam Surg Appl. 2015;37:19-25. 